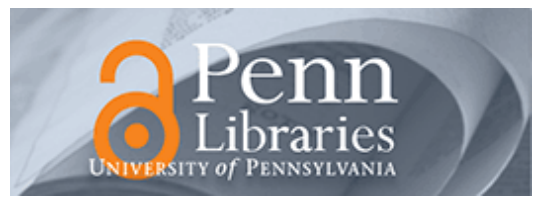

University of Pennsylvania ScholarlyCommons

January 2004

\title{
Four Myths About America's Teacher Quality Problem
}

Richard Ingersoll

University of Pennsylvania, rmi@upenn.edu

Follow this and additional works at: https://repository.upenn.edu/gse_pubs

\section{Recommended Citation}

Ingersoll, R. (2004). Four Myths About America's Teacher Quality Problem. Retrieved from

https://repository.upenn.edu/gse_pubs/29

Reprinted from Developing the Teacher Workforce, 103rd Yearbook of the National Society for the Study of Education, edited by Mark A. Smylie and Debra Miretzky (Chicago, University of Chicago Press, 2004), pages 1-33.

This paper is posted at ScholarlyCommons. https://repository.upenn.edu/gse_pubs/29

For more information, please contact repository@pobox.upenn.edu. 


\title{
Four Myths About America's Teacher Quality Problem
}

\author{
Abstract \\ Few educational issues have received more attention in recent times than the problem of ensuring that \\ our nation's elementary and secondary classrooms are all staffed with quality teachers. Concern with the \\ quality of teachers is neither unique nor surprising. Elementary and secondary schooling are mandatory in \\ the United States, and children are legally placed into the custody of teachers for a significant portion of \\ their lives. The quality of teachers and teaching are undoubtedly among the most important factors \\ shaping the learning and growth of students. Moreover, the largest single component of the cost of \\ education is teacher compensation.

\section{Comments} \\ Reprinted from Developing the Teacher Workforce, 103rd Yearbook of the National Society for the Study \\ of Education, edited by Mark A. Smylie and Debra Miretzky (Chicago, University of Chicago Press, 2004), \\ pages 1-33.
}


From:

Developing the Teacher Workforce,

$103^{\text {rd }}$ Yearbook of the National Society for the Study of Education

Edited by M. Smylie and D. Miretzky.

Part One

University of Chicago Press. (2004)

\title{
CHAPTERS
}

\author{
CHAPTER 1
}

\section{Four Mytbs About America's \\ Teacher Quality Problem}

RICHARD M. INGERSOLL

Few educational issues have received more attention in recent times than the problem of ensuring that our nation's elementary and secondary classrooms are all staffed with quality teachers. Concern with the quality of teachers is neither unique nor surprising. Elementary and secondary schooling are mandatory in the United States, and children are legally placed into the custody of teachers for a significant portion of their lives. The quality of teachers and teaching are undoubtedly among the most important factors shaping the learning and growth of students. Moreover, the largest single component of the cost of education is teacher compensation. Especially since the publication of the seminal report $A$ Nation at Risk (National Commission on Excellence in Education, 1983), a seemingly endless stream of studies, commissions, and national reports have targeted teacher quality as one of the central problems facing schools. Such critics have blamed the performance of teachers for numerous societal ills-the erosion of American economic competitiveness and productivity, the decline in student academic achievement, teenage pregnancy, juvenile delinquency and crime, the coarsening of our everyday discourse and culture, a decline in morals, gender and racial discrimination, and on and on.

As a result, in recent years reformers at the federal, state, and local levels have pushed a host of initiatives and programs seeking to upgrade the quality of teachers. These include a variety of teacher recruitment

Richard M. Ingersoll is Associate Professor of education and sociology at the University of Pennsylvania. 
initiatives, increased teacher training and retraining requirements, improved teacher licensing examinations, performance standards, more rigorous teacher evaluation, merit pay programs and, most recently, state and national accountability mechanisms.

Although ensuring that our nation's classrooms are all staffed with quality teachers is a perennially important issue in our schools, it is also among the most misunderstood. This misunderstanding centers on the supposed sources of the problem-the reasons behind the purportedly low quality of teaching in American schools-and has undermined the success of reform efforts. Underlying much of the criticism and reforms is a series of assumptions and claims as to the sources of the problems plaguing the teaching occupation. In this chapter I will focus on four of these.

The first is that the teaching occupation is plagued by unusually restrictive and unnecessary entry barriers-teacher training and teacher licensing requirements, in particular. In this view, as a result of these rigid bureaucratic regulations large numbers of high-quality candidates are discouraged from getting into the occupation.

The second is that severe teacher shortages are confronting our elementary and secondary schools, and our traditional teacher preparation sources are simply not producing sufficient numbers of teachers to meet the demand. Restrictive entry requirements may exacerbate this situation, but at the root of this school staffing crisis, according to this view, are two converging macro demographic trends-increasing student enrollments and increasing teacher attrition due to a "graying" teaching force. The resulting shortfalls of teachers, the argument continues, are forcing many school systems to resort to lowering standards to fill teaching openings, inevitably resulting in high levels of underqualified teachers.

The third is that the teaching force is inadequately trained and prepared. Unlike the first view, this perspective argues that entry into the occupation is not restrictive enough. In this view, the preservice preparation of teachers in college or university training programs and state certification standards all too often lack adequate rigor, breadth, and depth, especially in academic and substantive coursework, resulting in high levels of underqualified teachers.

The fourth and final claim I will examine has to do with the control and accountability of the teaching force once on the job. Schools, this view claims, are far too loose, too disorganized, and lack appropriate control, especially regarding their primary activity - the work of teachers with students. Teachers are not held accountable and simply do what 
they want behind the closed doors of their classrooms. The predictable result, this view holds, is low-quality performance on the part of teachers.

These four claims are, of course, not the only explanations given for the problem of low-quality teachers and teaching, nor are these views universally believed. Indeed, each is the subject of much contention-and proponents of one may be opponents of another. But all are prominent views, all are part of the conventional wisdom as to what ails teaching, and all have had an impact on reform and policy.

The thesis of this chapter, however, is that each is largely incorrect. My theoretical perspective is drawn from the sociology of organizations, occupations, and work. My operating premise, drawn from this perspective, is that fully understanding issues of teacher quality requires examining the character of the teaching occupation and the social and organizational contexts in which teachers work. A close look at the best data available from this perspective, I argue, shows that each of these views involves a wrong diagnosis and a wrong prescription. In the following sections I review each of the above views and explain why I believe each provides an inaccurate explanation of the problems plaguing the teaching occupation. I then offer an alternative hypothesis to explain the problems undermining the quality of teachers and teaching.

\section{Overly Restrictive Occupational Entry}

Entry into many occupations and professions is regulated. That is, entry into many kinds of work typically requires a license, which is obtained only after completion of an officially sanctioned training program and passage of examinations. Indeed, it can be illegal to do many kinds of work, from plumbing or hairstyling to law or medicine, without a license. These credentials serve as screening or "gatekeeping" devices. Their official rationale is protection of the interests of the public by assuring that practitioners hold an agreed-upon level of knowledge and skill and by filtering out those who are unable to pass over these "bars" and "hurdles."

Rigorous entry requirements are one of the hallmarks of the traditional or established professions, such as law, medicine, university teaching, engineering, and science. Among those who study work and occupations, the underlying and most important quality distinguishing professions from other kinds of occupations is the degree of expertise and complexity involved in the work itself. In this view, professional work involves highly complex sets of skills, intellectual functioning, 
and knowledge that is not easily acquired and not widely held. For this reason, professions are often referred to as the "knowledge-based" occupations. Accordingly, professions are usually more selective and characterized by higher training bars and narrower entry gates than nonprofessional occupations (Hall, 1968; Hodson \& Sullivan, 1995). The importance of entry requirements is evidenced by the practice, especially common among those employed in the traditional professions, such as physicians, dentists, architects, and attorneys, of prominently displaying official documentation of their credentials in their offices.

Given the importance of credentials, especially in the traditional professions, the content and rigor of the licensing requirements for new teachers has been an important issue in school reform. (In teaching, licenses are usually referred to as teaching certificates.) But it has also been a source of contention. On one side are those who argue that entry into teaching should be more highly restricted, as in the traditional professions. From this viewpoint, upgrading the training and certification standards required of new teachers will upgrade the quality of teaching (see, e.g., National Commission on Teaching and America's Future, 1996, 1997), a perspective to which I will return.

On the other side are those who argue that entry into the teaching occupation is already plagued by unusually restrictive and unnecessarily rigid bureaucratic entry barriers (e.g., Ballou, 1996; Finn, Kanstoroom, \& Petrilli, 1999; Hanushek \& Rivkin, 2004). From this viewpoint, traditional teacher training and state certification requirements, in particular, are akin to monopolistic practices. These critics argue that there is no solid empirical research documenting the value of such entry requirements. These regulations, they charge, are motivated less by an interest in protecting the public and more by a desire to protect the interests of those in the occupation. As a result, this view holds, large numbers of high-quality candidates are discouraged from getting into the occupation. By doing away with these impediments, this argument concludes, schools could finally recruit the kinds and numbers of candidates they deem best, and this would solve the quality problems that plague teaching.

There are a number of different variants of the anti-restrictiveentry perspective. One of the more popular variants favors a training model analogous to that dominant in higher education. The preservice preparation of professors often includes little formal training in instructional methods. Similarly, from this perspective, having an academic degree in a particular subject is sufficient to be a qualified secondary school teacher in that subject. Content or subject knowledge-knowing 
what to teach-is considered of primary importance for a qualified teacher. Formal training in teaching and pedagogical methods-knowing bow to teach-is considered less necessary (e.g., Finn, Kanstoroom, \& Petrilli, 1999).

Another variant of the anti-restrictive-entry perspective is motivated by concern for the demographic diversity of the teaching force. From this viewpoint, teaching's entry requirements result in reduced numbers of minority candidates entering the occupation, either because the requirements are themselves racially or ethnically biased, or because they screen out otherwise worthwhile candidates who are unable to pass over particular hurdles because of an underprivileged background (see, e.g., Villegas \& Lucas, this volume, chapter 3 ).

Proponents of the anti-restrictive entry perspective have pushed a range of initiatives, all of which involve a loosening of the traditional entry gates. Examples include alternative certification programs, whereby college graduates can postpone formal education training, obtain an emergency teaching certificate, and begin teaching immediately; and Peace Corps-like programs, such as Teach for America, which seek to lure the "best and brightest" into understaffed schools. It is important to note that proponents of these alternative routes into the occupation seek the same objective as those who propose to upgrade existing entry standards and programs--enhanced recruitment of higher quality candidates into teaching.

To be sure, there are at least two problems with existing teaching entry requirements. First, such requirements sometimes keep out quality candidates. Not everyone needs such qualifications to be a quality teacher. There are no doubt some individuals who are able to teach anything well, regardless of how few credentials they have. Moreover, especially in the absence of subsequent commensurate rewards, otherwise qualified candidates might be discouraged by the initial commitment and costs incurred by these entry hurdles. According to some, historically this has been the case in teaching. Attempts to upgrade the status of the occupation through more rigorous training and licensing standards or more selective entry gates appear to have often resulted in decreases in male entrants to teaching, who were eligible for, and more attracted to, occupations with better rewards (Strober \& Tyack, 1980).

The second, and converse, problem with occupational entry barriers is that they sometimes do not keep out some who ought not be in a particular line of work. Entry selection criteria and mechanisms can be crude and sometimes fail. Moreover, the training itself can be flawed or of low quality. Having obtained credentials and completed exams 
does not, of course, guarantee that an individual is a quality teacher, nor even a qualified teacher. There are no doubt some individuals who are unable to teach anything well, regardless of how many hurdles they have passed and credentials they have obtained.

But these two problems exist in all occupations and professions. There are no doubt otherwise qualified individuals who cannot practice law because they did not complete a law school program and pass a state bar exam. Conversely, there are no doubt individuals who did complete law school and did pass a bar exam, but who ought not be practicing lawyers. Indeed, a major criticism of the traditional professions, like medicine and law, is that they have become monopolistic and have too little accountability to their clients. For example, critics of medicine hold that doctors do not adequately police theit own ranks, and the public has few mechanisms to monitor or sanction incompetent doctors (Freidson, 1986). It is useful to place teaching's entry requirements, and the criticisms of them, in this context. The restrictiveness of occupational entry requirements is relative, and when evaluating the rules governing a particular occupation one must always pose the question, compared to what?

\section{An Easy-In/Easy-Out Occupation}

Compared with other developed nations, entry into the teaching occupation in the United States is not especially restrictive. Recent cross-national data indicate that the filters and requirements embedded in the process of becoming a teacher in the United States are less rigorous, less arduous, and less lengthy than those in a number of other countries, including Australia, England, Japan, Korea, the Netherlands, Hong Kong, and Singapore (Wang et al., 2003).

Moreover, the argument that entry into teaching is unusually restrictive stands in contrast to the perspective long held by organization theorists and among those who study work, organizations, and occupations in general. From a cross-occupational perspective, teaching has long been characterized as an easy-in /easy-out occupation. Compared with many other occupations and, in particular, compared with the traditional professions, teaching has a relatively low entry bar and a relatively wide entry gate (Etzioni, 1969; Ingersoll, 2000). There are some occupations, such as journalism, that do not require specialized training at either the undergraduate or graduate levels. However, many do require specialized training, often at an advanced level. Becoming a professor, lawyer, or dentist, for example, requires graduate-level training. This is also increasingly true for becoming an architect or engineer. 
Other professions, such as accounting, do not require graduate-level training but do have relatively rigorous entry exams.

In his classic study of teaching, Lortie (1975) drew attention to a number of mechanisms that facilitate ease of entry into teaching. First, teacher training is relatively accessible. Beginning in the early part of the 20th century, the states created large numbers of low-cost, dispersed, and nonelitist teacher training institutions. Another aspect that facilitates entry is what Lortie calls "contingent schooling"-training programs geared to the needs of recipients and accessible to those already teaching. Persistors can increase their investiment in occupational training, while others can choose to restrict their commitment to the minimum required. Teaching also has a relatively wide "decision range"-individuals can decide to become teachers at any number of points in their life span. Finally, most of those who desire to enter the teaching occupation are free to do so-individuals choose the occupation, not vice versa- a characteristic Lortie labeled the "subjective warrant." In contrast, the opposite prevails in many occupations and most traditional professions. Especially among the latter, occupational gatekeepers have a large say in choosing new members, and not all who desire to enter are allowed to do so.

In recent years, there has been a movement in a number of states to strengthen teacher certification standards. In the 1999-2000 school year, about $92 \%$ of public school teachers held a regular or full stateissued teaching certificate. Another $4 \%$ held only a temporary, emergency, or provisional certificate. About $4 \%$ of public school teachers held no teaching certificate of any type. Moreover, although not required in many states, a majority of private school teachers also are certified. In the 1999-2000 school year, about $59 \%$ of private school teachers held a regular or full teaching certificate. Another $4 \%$ held only a temporary, emergency, or provisional certificate. About $37 \%$ of private school teachers held no teaching certificate of any type (Ingersoll, 2004). By 2000, 74\% of states required written tests of basic skills for those teachers entering the occupation, $58 \%$ had tests of content knowledge, and $48 \%$ had written tests for subject-specific pedagogy (Education Week, 2000). But the requirements to become an elementary- or secondary-level teacher are still neither uniform nor considered rigorous. While some states have implemented more rigorous certification criteria, others have passed legislation that waives requirements to meet certification criteria-an ambivalence reflecting the two opposing views described above. 
Ironically, although tcaching's entry training and licensing requirements are lower than those for many other occupations and lower in the United States than in some other nations, they appear to be subject to far more scrutiny than those in other occupations. There is an extensive body of empirical research, going back decades, devoted to evaluating the effects of teacher credentials on student performance (for reviews, see Allen, 2003; Murnane \& Raizen, 1988). Accurately isolating and capturing the effects of teachers' qualifications on their students' achievement is difficult, and not surprisingly, the results from this literature are often contradictory. However, despite these problems, and contrary to the claims of the skeptics, many studies have indeed found teacher education and training, of one sort or another, to be significantly related to increases in student achievement (see, e.g., Greenwald, Hedges, \& Laine, 1996; Raudenbush, Fotiu, \& Cheong, 1999).

Such scrutiny of the value entry requirements add is useful from the perspective of the public interest. But this level of scrutiny also appears to be highly selective. In preliminary searches I have been unable to find analogous evaluative research-an effects literature-for a number of other occupations and professions. To be sure, there does appear to be interest in determining the best form of preparation of, for example, engineers and lawyers. But I have failed to find much debate over whether advanced training and education are necessary for these jobs. For example, there does not appear to be a "professor effects" literature that examines whether professors' qualifications have a positive effect on student achievement or on research quality (for a review, see e.g., Pascarella \& Terenzini, 1991). Nevertheless almost all universities require a doctoral degree for academic positions.

My point is not to deny that existing training and entry requirements for teaching may be at times irrelevant, or that some worthy individuals have been denied entry into the occupation, or that financial obstacles and low-quality preparation programs exist, or that some entry requirements may be biased for or against particular groups. $\mathrm{My}$ point is simply that entry into the teaching occupation is relatively easy as compared to many other occupations, and as compared to the traditional professions.

The prescriptions offered by critics of teaching's entry requirements may be successful. Further loosening the entry gates to teaching may increase the flow of quality candidates, especially in the short term. But they may also do the opposite. If loosening the entry requirements involves further lowering an already low bar, this may make 
the occupation less attractive and reduce the flow of quality candidates, especially in the long term. Moreover, if new entry requirements neglect to provide particular kinds of practical training needed to function on the job, an additional burden would be placed on schools themselves to provide such training. In either event, regardless of the impact on the supply of new recruits, this kind of occupational deregulation and gate loosening, alone, will not solve the larger problem of ensuring a quality teacher in every classroom if it does not also address the issue of retention-the subject of the next section.

\section{Severe Teacher Shortages}

A second and related explanation for the problem of low-quality teaching in U.S. schools is teacher shortages. In this second view, the problem is that the supply of new teachers is insufficient to keep up with the demand. Restrictive entry requirements may exacerbate this condition, but the root of this gap, it is widely believed, is a dramatic increase in the demand for new teachers primarily resulting from two converging demographic trends-increasing student enrollments and increasing teacher retirements due to a "graying" teaching force. Shortfalls of teachers, this argument continues, have meant that many school systems have not been able to find qualified candidates to fill their openings, inevitably resulting in the hiring of underqualified teachers and ultimately lowering school performance. Teacher shortage crises are not new to the K-12 education system. In the early and mid-1980s, a series of highly publicized reports warned of an impending shortage crisis for the teaching occupation (see, e.g., DarlingHammond, 1984; National Academy of Sciences, 1987; National Commission on Excellence in Education, 1983; for reviews of this issue, see Boe \& Gilford, 1992). Indeed, teacher shortages have been seen as a cyclic threat for decades (Weaver, 1983).

The prevailing policy response to these school staffing problems has been to attempt to increase the supply of teachers through a wide range of recruitment initiatives. Some of these involve a loosening of entry requirements, some do not. There are career-change programs, such as the federally funded Troops to Teachers program, which aim to entice professionals to become teachers. Some school districts have recruited teacher candidates from other countries. Financial incentives such as signing bonuses, student loan forgiveness, housing assistance, and tuition reimbursement have all been used to aid recruitment (Hirsch, Koppich, \& Knapp, 2001). 
The best data for understanding these issues come from the nationally representative Schools and Staffing Survey (SASS), conducted by the National Center for Education Statistics (NCES), the statistical arm of the U.S. Department of Education. Begun in the late 1980s, this is the largest and most comprehensive data source available on teachers and school staffing. Indeed, it was originally created because of a dearth of information on these very problems and issues. Over the past few years I have undertaken a series of analyses of these data to examine what is behind the teacher shortage. Below I will summarize the results of this research. (The data and discussion below are drawn from Ingersoll, 2001, 2003b). From these analyses, I have concluded that the above efforts alone will not solve the problem schools have staffing classrooms with qualified teachers.

The data show that the conventional wisdom on teacher shortages is partly correct. Consistent with shortage predictions, demand for teachers has increased over the past two decades. Since the mid-1980s student enrollments have increased, teacher retirements have also increased, most schools have had job openings for teachers, and the size of the elementary and secondary teaching workforce has increased. Most important, the data tell us that substantial numbers of schools have experienced difficulties finding qualified candidates to fill their teaching position openings.

After that the data and conventional wisdom begin to diverge. National data on the supply of teachers trained, licensed, and certified each year are difficult to obtain. One of the best sources is NCES's Integrated Postsecondary Educational Data System (IPEDS). This source collects national data on the number of postsecondary degree completions, by field and by year. These data suggest that, contrary to the conventional wisdom, there are overall more than enough prospective teachers produced each vear in the United States. But there are also some important limitations to these data. An overall surplus of newly trained teachers does not, of course, mean there are sufficient numbers of graduates produced in each field. A large proportion of education degree completions are in elementary education. The data are unclear on whether a sufficient quantity of teachers is produced each year in such fields as math, science, and special education.

On the other hand, the IPEDS data on degree completions underestimate the supply of newly qualified teachers because this database does not include recipients of undergraduate degrees in areas other than education who also completed the requirements for certification. Moreover, newly qualified candidates, as counted in the IPEDS data, 
are only one source of new hires in schools. Far more of those newly hired into schools each year are from what is often referred to as the "reserve pool." These include delayed entrants, those who completed teacher training in prior years but who have never taught, and reentrants, former teachers who return to teaching after a hiatus. The addition of these other types and sources of teachers lend support to the argument that there are more than enough teachers supplied each year.

However, the key question is not whether the overall national supply of teachers is adequate or inadequate but rather which schools have staffing problems and teacher supply and demand imbalances. Even in the same jurisdiction, the degree of staffing problems can vary greatly among different types of schools, and sites ostensibly drawing from the same teacher supply pool can have significantly different staffing scenarios. Some analysts have found, for example, that in the same metropolitan area in the same year, some schools have extensive waiting lists of qualified candidates for their teaching job openings, while other nearby schools have great difficulty filling their teaching job openings with qualified candidates (National Commission on Teaching and America's Future, 1997). This suggests that imbalances between demand and supply must be examined at the organizational level to be fully understood-an issue to which I will return.

There is also another problem with the conventional wisdom on shortages. The SASS data show that the demand for new teachers and subsequent staffing difficulties confronting schools are not primarily due to student enrollment and teacher retirement increases, as widely believed. Most of the demand for teachers and hiring is simply to replace teachers who have recently left their teaching jobs, and most of this teacher turnover has little to do with a "graying workforce."

\section{The Revolving Door}

The data tell us that large numbers of teachers leave their positions each year. I have found that, as an occupation, teaching has higher turnover rates than a number of higher-status professions (such as professors and scientific professionals), about the same as other traditionally female occupations (such as nurses), and less turnover than some lower-status, lower-skill occupations (such as clerical workers). But teaching is also a relatively large occupation. Teachers represent $4 \%$ of the entire civilian workforce. There are, for example, more than twice as many elementary and secondary teachers as there are registered nurses, and there are five times as many teachers as there are either lawyers or professors. The sheer size of the teaching force combined 
with its levels of annual turnover means that there are large numbers of teachers in some kind of job transition each year. For example, the data show that over the course of the 1999-2000 school year, well over a million teachers-almost one third of this large workforce-moved into, between, or out of schools. The image that these data suggest is one of a revolving door. The latter is a major, but unheralded, factor behind the difficulties many schools have in ensuring that their classrooms are staffed with qualified teachers.

Of course, not all teacher turnover is negative. Some degree of employee turnover is normal and beneficial in any workplace. Too little turnover of employees is tied to stagnancy in organizations; effective organizations usually both promote and benefit from a limited degree of turnover by eliminating low-caliber performers and bringing in new blood to facilitate innovation. But a revolving door is costly. In the corporate sector it has long been recognized that high employee turnover means substantial recruitment and training costs and is both the cause and effect of productivity problems (e.g., Bluedorn, 1982; Hom \& Griffeth, 1995; Mobley 1982; Price, 1977, 1989). In contrast to the corporate sector, however, there has been very little attention paid to the impact of employee turnover in education. One notable exception is a recent attempt to quantify the costs of teacher turnover in Texas. This study concluded that teacher turnover costs the state hundreds of millions of dollars each vear (Texas Center for Educational Research, 2000).

Some of the costs and consequences of employee turnover are more easily measured than others. One type of cost that is less easily quantified concerns the negative consequences of high turnover for organizational performance in work sites, like schools, requiring extensive interaction among participants. Much research has shown that the good school, like the good family, is characterized by a sense of belonging, continuity, and community (e.g., Coleman \& Hoffer, 1987; Durkheim, 1925/1961; Grant, 1988; Kirst, 1989; Parsons, 1959; Waller, 1932). Continuity and coherence are especially important for long-term school improvement efforts. The capacity of schools to carry out successful reform often depends on the continuing presence of sufficient numbers of staff committed to the change (Fullan, 1991; Smylie \& Wenzel, 2003). Thus, from an organizational perspective, teacher turnover is of concern not simply because it mav be an indicator of sites of so-called shortages but because of its relationship to school cohesion and, in turn, school performance.

The data also show that turnover varies greatly among different kinds of teachers. Teaching is an occupation that loses large numbers 
of its new members very early in their careers-long before their retirement years. A number of studies have found that after just five years, between 40 and 50 percent of all beginning teachers have left teaching altogether (Hafner \& Owings, 1991; Huling-Austin, 1990; Murnane et al., 1991). Other studies have also found that the "best and brightest" among new teachers-those with higher test scores, such as on the SAT and the National Teacher Exam-are the most likely to leave (e.g., Henke, Chen, \& Geis, 2000; Murnane et al.; Schlecty \& Vance, 1981; Weaver, 1983). Moreover, the SASS data show that turnover also varies greatly among different kinds of schools. High-poverty public schools have far higher teacher turnover rates than do more affluent schools. Urban public schools have more turnover than do suburban and rural public schools.

These data raise two important questions: why is there so much teacher turnover, and why are these rates so dramatically different between schools?

Contrary to conventional wisdom, the SASS data show that retirement accounts for only a small part-about one eighth-of the total departures. Far more significant are personal reasons for leaving, such as pregnancy, child rearing, health problems, and family moves. These are a normal part of life and common to all workplaces. There are also two other, equally significant reasons for teacher turnover-job dissatisfaction and the desire to pursue a better job inside or outside of the education field. Together, these two reasons are the most prominent source of turnover and account for almost half of all departures each year. Of those who leave because of job dissatisfaction, most link their departures to several key factors: low salaries, lack of support from school administrators, lack of student motivation, student discipline problems, and lack of teacher influence over school decision making.

What can we conclude from the data about the validity of the teacher shortage diagnosis and its attendant prescriptions? The data tell us that the root of the problem is not shortages, in the sense of too few teachers being produced, but rather turnover-too many teachers departing prior to retirement. Thus, the solution is not solely recruitment but also retention. In plain terms, recruiting thousands of new candidates into teaching alone will not solve the teacher crisis if 40 to 50 percent of these new recruits leave the occupation in a few short years, as the data tell us they do. The image that comes to mind is that of a bucket rapidly losing water because there are holes in the bottom. Pouring more water into the bucket will not be the answer if the holes are not first patched. 
Of course, nothing in the data suggests that plugging these holes will be easy. But the data do make clear that schools are not simply victims of inexorable societal demographic trends, and that there is a significant role for the organization of schools as workplaces and the treatment of teachers as employees in these workplaces. Improving the workplace conditions in our schools, as discussed above, would contribute to lower rates of teacher turnover, which in turn would slow down the revolving door, help ensure that every classroom is staffed with qualified teachers, and ultimately increase the performance of schools.

\section{Too Many Underqualified Teachers}

A third prominent explanation of low-quality teaching focuses on the qualifications, training, and licensing of prospective teachers. Rather than too many requirements, as in the earlier anti-restrictive entry perspective, this third view argues the opposite. In this view, a major source of the problem is inadequate and insufficient preservice training and certification standards. In response, reformers in many states have pushed tougher certification requirements and more rigorous coursework requirements for teaching candidates. However, like many similarly worthwhile reforms, these efforts alone will also not solve the problem because they do not address some key causes.

One of the least recognized of these causes is the problem of outof-field teaching-teachers being assigned to teach subjects that do not match their training or education. This is a crucial issue because highly qualified teachers may actually become highly unqualified if they are assigned to teach subjects for which they have little training or education. There has been little recognition of this problem, however, largely because of an absence of accurate data-a situation remedied with the release of the SASS data in the early 1990s.

In analyses of these data, summarized below, I have found that outof-field teaching is a chronic and widespread problem (the data and discussion below are drawn from Ingersoll, 1999, 2004). The data show, for example, that about one third of all secondary (grades 7-12) math classes are taught by teachers who have neither a major nor a minor in math or a related discipline such as physics, statistics, engineering, or math education. Almost one quarter of all secondary school English classes are taught by teachers who have neither a major nor minor in English or a related discipline such as literature, communications, speech, journalism, English education, or reading education. The situation is even worse within such broad fields as science and social studies. 
Teachers in these departments are routinely required to teach any of a wide array of subjects outside of their discipline but still within the larger field. As a result, over half of all secondary school students enrolled in physical science classes (chemistry, physics, earth science, or space science) are taught by teachers who have neither a major nor a minor in any of these physical sciences. Moreover, more than half of all secondary school history students in this country are taught by teachers with neither a major nor a minor in history. The actual numbers of students affected are not trivial. For English, math, and history, several million secondary school students a year in each discipline are taught by teachers without a major or minor in the field.

Out-of-field teaching also varies greatly across teachers and schools. For instance, recently hired teachers are more often assigned to teach subjects out of their fields of training than are more experienced teachers. Low-income public schools have higher levels of out-of-field teaching than do schools in more affluent communities. Particularly notable, however, is the effect of school size; small schools have higher levels of out-offield teaching. There are also differences within schools. Lower-achieving classes are more often taught by teachers without a major or minor in the field than are higher-achieving classes. Junior high classes are also more likely to be taught by out-of-field teachers than are senior high classes.

The data clearly indicate that out-of-field teaching is widespread. Some of it takes place in over half of all secondary schools in the United States in any given year-both rural and urban schools and both affluent and low-income schools. Each year over one fifth of the public teaching force for grades 7 to 12 does some out-of-field teaching. No matter how it is defined, the data show that levels of out-of-field teaching are alarming. I found, for example, that similarly high numbers of teachers do not have teaching certificates in their assigned fields. Indeed, when I upgraded the definition of a qualified teacher to include only those who held botb a college major and a teaching certificate in the field, the amount of out-of-field teaching substantially increased. Moreover, outof-field teaching does not appear to be going away; I found that levels of out-of-field teaching have changed little over the past decade.

The crucial question, and the source of great misunderstanding, is: why are so many teachers teaching subjects for which they have little background?

\section{The Sources of Out-of-Field Teacbing}

Typically, policymakers, commentators, and researchers have assumed two related explanations for the continuing problem of out-of-field 
teaching. One involves the adequacy of teacher training; the other involves the adequacy of teacher supply. The first blames teacher preparation programs or state certification standards (e.g., American Council on Education, 1999; Committee for Economic Development, 1996; Darling-Hammond, 1999). One subset of this view argues that the problem can be remedied by requiring prospective teachers to complete a "real" undergraduate major in an academic discipline.

It certainly may be correct that some teacher preparation programs and teacher certification standards suffer from shortcomings, but these problems do not explain the practice of out-of-field teaching. The SASS data indicate that most teachers have completed basic college education and teacher training. Ninety-nine percent of public school teachers hold at least a bachelor's degree and almost half hold a master's degree or higher. Moreover, as mentioned earlier, in the 1999-2000 school year about $92 \%$ of public school teachers held a regular or full teaching certificate. Another $4 \%$ held only a temporary, emergency, or provisional certificate. About $4 \%$ of public school teachers held no teaching certificate of any type.

These data appear to conflict with conventional wisdom. In recent years, much attention has been focused on the plight of school districts, especially those serving low-income, urban communities that, according to popular belief, have been forced to hire significant numbers of uncertified teachers to fill their teaching vacancies. The national data suggest, however, that the number of teachers without a full certificate actually represents only a small proportion of the K-12 public teaching force.

My main point, however, is that the assumption that out-of-field teaching is due to teacher training deficits confounds and confuses two different sources of the problem of underqualified teaching; it mistakes teacher preservice education with teacher inservice assignment. The data show that those teaching out of field are typically fully qualified veterans with an average of 14 years of teaching experience who have been assigned to teach part of their day in fields that do not match their qualifications. At the secondary level, these misassignments typically involve one or two classes out of a normal daily schedule of five classes.

Why then is there so much misassignment? The second explanation of the problem of out-of-field teaching offers an answer-teacher shortages. This view holds that shortfalls in the number of available teachers have led many school systems to resort to assigning teachers to teach out of their fields (see, e.g., National Commission on Teaching and America's Future, 1996, 1997). 
School staffing difficulties clearly are a factor in the degree of misassignment, but the data show that there are two problems with the shortage explanation for out-of-field teaching. First, it cannot explain the high levels of out-of-field teaching that the data indicate exist in fields that have long been known to have surpluses, such as English and social studies. Second, the data also indicate that about half of all misassigned teachers in any given year were employed in schools that reported no difficulties finding qualified candidates for their job openings that year.

The implications of these misdiagnoses for reform are important. The efforts by many states to recruit new teachers, to enhance their training, to enact more stringent certification standards, and to increase the use of testing for teaching candidates, although perhaps highly worthwhile, will not eliminate out-of-field teaching assignments and, thus, alone will not solve the problem of underqualified teaching in our nation's classrooms. In short, bringing in thousands of new candidates and mandating more rigorous coursework and certification requirements will help little if large numbers of such teachers continue to be assigned to teach subjects other than those for which they were educated or certified.

\section{Human Resource Management}

Rather than deficits in the qualifications and quantity of teachers, the data point in another direction. In a series of separate multivariate analyses designed to explore the sources of out-of-field teaching, I have found that the way schools are organized and teachers are managed accounts for as much of the problem of out-of-field teaching as do inadequacies in the supply of teachers. For example, I have found that, after controlling for school recruitment and hiring difficulties and for school demographic characteristics, factors such as the quality of principal leadership, average class sizes, the character of the oversight of school hiring practices provided by the larger district, and the strategies districts and schools use for teacher recruitment and hiring are all significantly related to the amount of out-of-field teaching in schools (Ingersoll, 2004).

The data tell us that decisions concerning the allocation of teaching assignments is usually the prerogative of school principals. These administrators are faced with resolving the tension between the many expectations and demands state and federal governments place on schools and the limited resources schools receive. School managers are charged with the often difficult task of providing a broad array of programs and courses with limited resources, limited time, a limited budget, and a 
limited teaching staff (Delany, 1991). Principals' staffing decisions are further constrained by numerous factors, such as teacher employment contracts, which, among other things, typically stipulate that full-time secondary school teaching staff must teach five classes per day. But, within those constraints, principals have an unusual degree of discretion in these decisions. There has been little regulation of how teachers are employed and utilized once on the job. Teacher employment regulations have been weak or rarely enforced, and, finally, most states have routinely allowed local school administrators to bypass even the limited requirements that do exist (Education Week, 2000; Robinson, 1985). In this context, principals may find that assigning teachers to teach out of their fields is often more convenient, less expensive, and less time consuming than the alternatives.

For example, rather than finding and hiring a new part-time science teacher to teach two sections of a newly state-mandated science curriculum, a principal may find it more convenient to assign a couple of English and social studies teachers to each cover a section in science. If a teacher suddenly leaves in the middle of a semester, a principal may find it faster and cheaper to hire a readily available, but not fully qualified, substitute teacher, rather than conduct a formal search for a new teacher. When faced with the choice between hiring a fully qualified candidate for an English position or hiring a lesser-qualified candidate who is also willing to coach a major varsity sport, a principal may find it more convenient to do the latter. When faced with a tough choice between hiring an unqualified candidate for a science teacher position or doubling the class size for one of the fully qualified science teachers in the school, a principal might opt for the former choice. If a full-time music teacher is under contract, but student enrollment is sufficient to fill only three music classes, the principal may find it both necessary and cost-effective in a given semester to assign the music teacher to teach two classes in English, in addition to the three classes in music, in order to employ the teacher for a regular full-time complement of five classes per semester. If a school has three full-time social studies teachers but needs to offer 17 social studies courses, or the equivalent of 3.4 full-time positions, and also has four full-time English teachers but needs to offer only 18 English courses, or the equivalent of 3.6 full-time positions, one solution would be to assign one of the English teachers to teach three English courses and two social studies courses.

All of these managerial choices to misassign teachers may save time and money for the school, and ultimately for the taxpayer, but 
they are not cost free. They are one of the largest sources of underqualified teachers in schools.

\section{A Lack of Workplace Control and Accountability}

A fourth and final explanation often given for low-quality teaching focuses on the management of teachers and schools. This view holds that schools are highly disorganized and lack appropriate control, especially regarding their primary activity-the work of teachers with students. These critics argue that school systems are marked by low standards, a lack of coherence and control, poor management, and little effort to ensure accountability. The predictable result, they hold, is poor performance on the part of teachers and students. In short, this viewpoint finds schools to be the epitome of inefficient and ineffective bureaucracy (for reviews, see Conley, 1991; Tyler, 1988).

Over the past several decades this viewpoint has drawn a great deal of theoretical and empirical support from the interdisciplinary field of organization theory and from social scientists who study organizations, occupations, and work in general. To analysts in these fields schools are an interesting anomaly-an odd case. From this viewpoint, schools are unusual because, although they appear to be like other large complex organizations, such as banks, agencies, offices, and plants, they do not act like them. In particular, they do not seem to have the degree of control and coordination that such organizations are supposed to have. Schools have all the outward characteristics of other complex organizations, such as a formal hierarchy, a specialized division of labor, and a formal structure of rules and regulations, but, in actuality, according to these organizational analysts, schools exert very little control of their employees and work processes. Because of this seemingly contradictory behavior, organization theorists have adopted a colorful vocabulary to identify such settings. Educational organizations, they hold, are extreme examples of "loosely coupled systems" and "organized anarchies” (see, e.g., Cohen, March, \& Olsen, 1972; Meyer \& Scott, 1983; Weick, 1976). In this view, schools are oddly de-bureaucratized bureaucracies and, paradoxically, disorganized organizations-a situation that, they conclude, is often satisfying and of benefit to the staff involved but also a source of inefficient and ineffective organizational performance.

For many of those who subscribe to this view, the obvious antidote to the ills of the education system is to increase the centralized control of schools and to hold teachers more accountable. In short, their 
objective has been to tighten the ship in one manner or another: increased teacher training and retraining requirements, standardized curricula and instructional programs, teacher licensing examinations, performance standards, more school and teacher evaluation, merit pay programs, and state and national education goals, standards, and testing (see, e.g., Callahan, 1962; Elmore, 2000; Finn, Kanstoroom, \& Petrilli, 1999).

But distinguishing the degree and character of accountability and control in schools, as in any organization, depends on where and how one looks. I found in an extensive project, summarized below, involving analyses of international data, SASS data, and data from my own ficld research in schools, that this "loosely coupled schools" perspective has overlooked and underestimated some of the most important sources and forms of organizational control and accountability in schools (the data and discussion below are drawn from Ingersoll, 2003a).

In the first place, how one defines the job of teaching is important. When it comes to assessing how centralized or decentralized schools are and examining how much input and autonomy teachers do or don't have, most researchers assume, reasonably enough, that classroom academic instruction is the primary goal and activity of schools and teachers, and the most important place to look for evidence. Analysts typically focus on who chooses textbooks, who decides classroom instructional techniques, and how much say teachers have over the determination of the curriculum. Moreover, when it comes to evaluating the organization of schooling, most analysts look at the effects of school characteristics on student academic achievement test scores. This approach makes sense, but it also misses a very important point.

Schools are not simply formal organizational entities engineered to deliver academic instruction, and schools do not simply teach children reading, writing, and arithmetic. Schools are also social institutions; they are akin to small societies whose purposes are in important ways like those of another social institution-the family. Schools are one of the major mechanisms for the socialization of children and youth. This is so fundamental and so obvious it is, understandably enough, easily forgotten and taken for granted. One of the central contributions of sociology, in particular, to the study of schooling has been to uncover and stress the importance of this fundamental social role. Sociologists hold that this social role involves two highly charged tasks, both of which profoundly shape the future lives of children. The first involves the rearing and parenting of the young-in short, teaching children how to behave. The second involves the sorting of the 
young according to their capacities and abilities, perhaps the most crucial part of which has become the determination of whether students are "college material" or not.

An empirical emphasis on the academic and instructional aspects of the job of teachers has meant a de-emphasis on these social dimensions of teaching in research on control in schools. However, to fully understand accountability and control in schools, it is necessary also to examine the control of these social aspects of the work of teachers in schools.

Second, assessments of organizational accountability and control are highly dependent on how one examines them. In school research, as in much organizational research, analysts often focus on the more direct, visible, and obvious mechanisms of control, accountability, and influence-such as rules and regulations, or "sticks and carrots." It is important to recognize, however, that control and accountability can be exerted in a wide array of ways in schools, as in other workplaces. Organizational analysts have shown that the most effective mechanisms by which employees are controlled are often embedded in the day-to-day organization of the work itself and, thus, can be taken for granted, invisible to insiders and outsiders alike (e.g., Braverman, 1974; Burawoy, 1979; Perrow, 1986).

\section{Who Controls Teachers' Work?}

Historically, in the United States, the control of elementary and secondary schooling developed in an unusual manner. In contrast to most European nations, public schooling in this country was originally begun on a highly democratized, localized basis. The resulting legacy is a current system of some 15,000 individual public school districts, governed by local school boards of citizens, each with legal responsibility for the administration and operation of publicly funded, universal, and mandatory elementary and secondary schooling. Local school districts in the United States are clearly no longer the autonomous bodies they once were. Nevertheless, the best international data available indicate that, despite these changes, schooling in the United States remains a relatively local affair in comparison with other nations.

Although the education system in the United States is relatively decentralized, schools themselves are not. Most public and private secondary schools are highly centralized internally. The SASS data show that although public and private school principals and public school governing boards often have substantial control over many key decisions in schools, teachers usually do not. As a result, teaching is an occupation beset by tension and imbalance between expectations and 
resources, responsibilities and powers. On one hand, the work of teaching-helping prepare, train, and rear the next generation of children-is both important and complex. But on the other hand, those who are entrusted with the training of this next generation are not entrusted with much control over many of the key decisions concerning their work. Perhaps not surprisingly, this is particularly true for those crucial and controversial activities that are most fundamentally social. The most highly controlled, most highly consequential, and most overlooked aspects of schools are the socializing and sorting of students that teachers do.

In my research I spent considerable time examining by what means and mechanisms, if any, administrators are able to exert control over the work of teachers and attempt to establish accountability in schools. I found that in schools, as in all bureaucratic organizations, there are large numbers of rules, policies, regulations, employee job descriptions, and standard operating procedures designed to direct and control the work of teachers. I also found that school administrators have numerous means, both formal and informal, by which they are able to supervise, discern, and evaluate whether teachers are complying with the rules and policies. In addition, I found that school administrators have numerous mechanisms, both formal and informal, to discipline or sanction those teachers who have not complied with the rules or have not performed adequately. A close look at schools reveals that administrators have a great deal of control over key resources and decisions crucial to the work of teachers, and these provide a range of direct and indirect levers-"sticks and carrots"- to exert accountability.

I also found that rules, regulations, supervision, and sanctions were not the only, nor perhaps the most effective, means of controlling the work of teachers. Teachers are also controlled in less visible and less direct ways. Schools are an odd mix of bureaucratic and non-bureaucratic characteristics. Some of these other genres of control are built into the formal structure of schools and the way the work of teachers is organized. Others are embedded in the workplace culture, the informal or social organization, of schools. Although these mechanisms are less direct and obvious than formal rules and regulations, they are no less real in their impact on what teachers actually do. Indeed, in some ways the pervasiveness of these other kinds of controls make it less necessary for school administrators to implement and require formal regulations and elaborate mechanisms of accountability. Higher-order decisions, over which teachers have little influence, set the parameters for lowerorder decisions delegated to teachers in their classrooms. The use of 
relatively crude and direct levers is not necessary because, by definition, little of consequence is actually delegated to teachers.

\section{The Teacber in the Middle}

These less obvious controls are reflected in the role of teachers in schools. Teachers are akin to men or women in the middle. A useful analogy is that of supervisors or foremen caught between the contradictory demands and needs of their superordinates (school administrators) and their subordinates (students). Teachers are not the workers who do the work themselves, nor are teachers part of the management of schools. Teachers are in charge of, and responsible for, the workers-their students. Although teachers are delegated limited input into crucial decisions concerning the management of schools and their own work, teachers are delegated a great deal of responsibility for the implementation of these decisions. Like other middlemen and middlewomen, teachers usually work alone and may have much latitude in seeing that their students carry out the tasks assigned to them. This responsibility and latitude can easily be mistaken for autonomy, especially regarding tasks within classrooms. A close look at the organization of the teaching job shows, however, that although it involves the delegation of much responsibility, it involves little real power.

A little recognized but telling illustration of this mixed and inbetween role is the widespread practice among teachers of spending their own money on classroom materials that they feel they need to do an adequate job with their students. Teachers often find, for a variety of reasons, that the school does not, or will not, provide the curriculum materials, stationery, and supplies they deem necessary. As the SASS data indicate, teachers have little access to, or control over, school discretionary funds. These monies must be requested through administrative channels, a sometimes frustrating and unsuccessful experience. A national survey of public school teachers conducted in 1990 by the Carnegie Foundation for the Advancement of Teaching found that teachers spent an average of about $\$ 250$ of their own money per semester (or about $\$ 500$ per year) for classroom materials and supplies they felt they needed to meet the needs of their students. Only $4 \%$ of the teaching force reported spending none of their own money for

such supplies that year. Similarly, the 1996 Survey on the Status of the American Public School Teacher, conducted by the National Education Association, found that public school teachers spent, on average, about $\$ 408$ of their own money that year for curriculum materials and classroom supplies. Only $6.3 \%$ reported spending none of their own 
money that year for such materials. Notably, this altruism was not merely a matter of youthful idealism; the data show that older teachers spent more of their own money than did younger teachers.

These data and indicators suggest a remarkable responsibility and accountability on the part of individuals in the face of a remarkable lack of responsibility or accountability on the part of the organizations that employ them. These nationally representative data suggest that in 1996, a workforce numbering about three million teachers donated a total of well over one billion dollars of educational materials to their schools. This kind of teacher subsidization of the school system received unprecedented recognition in federal legislation, proposed by the Bush administration in 2001, to provide tax deductions to teachers for their out-of-pocket expenditures for classroom materials.

Teacher financial subsidization of public schools is all the more notable because teaching is a relatively low-paying occupation. The SASS data indicate that the average starting salary for a public school teacher in the 1999-2000 school year was about $\$ 26,000$, and the average highest possible salary was less than $\$ 50,000$. The salaries of new college graduates who become teachers have long been consistently and considerably below those of new college graduates who choose most other occupations (Ingersoll, 2000). For instance, the average salary (one year after graduation) for 1993 college graduates who became teachers was almost $50 \%$ less than the average starting salary of their classmates who took computer science jobs. Moreover, this disparity remains throughout the career span. Comparing total yearly income, teachers earn less than those in many other occupations and far less than most traditional professionals. Data from a 1991 national survey show that the average annual earnings of teachers were one fifth the average annual earnings of physicians, one third that of lawyers, and just over half of the earnings of college and university professors (Ingersoll, 2000). Using these salary data, it is possible to make a crude calculation of an equivalent level of personal accountability for these other occupations. The lower $\$ 408$ figure for out-of-pocket expenditures reported in the NEA survey represented about $1.5 \%$ of the average public school teacher salary that year. Thus, a rough equivalent of average out-of-pocket expenditures for the purchase of materials necessary to serve their clients would come to (in 1991 dollars): about $\$ 550$ per year for professors; about $\$ 820$ per year for lawyers; and about $\$ 1400$ per year for doctors.

From the outside, this workplace ethos of individual responsibility and accountability may appear to involve a substantial degree of autonomy and discretion on the part of teachers. Although the structure of 
some schools may isolate and overextend them, teachers do appear to have a wide latitude of choice in how to respond to and cope with the manner in which their work is organized. From the loosely-coupledschools perspective, this kind of autonomy held by teachers is considerable. However, from a workplace control perspective (e.g., Braverman, 1974; Burawoy, 1979; Simpson, 1985), such an interpretation misconstrues these phenomena. From this counter viewpoint, what may appear from the outside to be teacher autonomy and organizational decentralization is actually a form of centralized organizational control. The substitution of greater responsibility and greater latitude for a system of rigid rules and routinized procedures is not a form of decentralization and employee empowerment, but the opposite-an alternative and highly effective, yet highly invisible, form of centralized organizational control. Seen this way, the key distinction is between the delegation of responsibility and the delegation of power.

The critics of looseness in schools are correct-there is no question that the public has a right and, indeed, an obligation to be concerned with the performance of teachers. Schools, like all organizations designed to serve the collective needs of the public, need to be accountable to that public. However, the tighten-the-ship perspective and many of the reforms to come out of it commonly suffer from several problems. The first involves the accuracy of their diagnosis. The data show that there exists a high degree of centralization in schools and a lack of teacher control, rather than the opposite.

Second, accountability reforms are often unfair. For instance, proponents of top-down accountability reforms tend to overlook the unusual character of the teaching workforce. It is common among these policymakers and reformers to question and criticize the caliber and quality of teachers. A litany of such critics have told us again and again that teachers lack sufficient accountability, engagement, and commitment. But the data suggest that teachers have an unusual degree of public-service orientation and commitment compared with others. Unrecognized and unappreciated by these critics is the extent to which the teaching workforce is a source of human, social, and even financial capital in schools.

Third, for the above reasons accountability reforms often do not work. Top-down reforms draw attention to an important set of needsaccountability on the part of those doing the work. But these kinds of reforms sometimes overlook another, equally important set of needsfor autonomy and the good will of those doing the work. Too much organizational control may deny teachers the very control and flexibility 
they need to do the job effectively and may undermine their motivation. A high degree of organizational control may squander a valuable human resource - the unusual degree of commitment of those who enter the teaching occupation. Having little say in the terms, processes, and outcomes of their work may deny teachers the opportunity to feel that they are doing worthwhile work - the very reason many of them came into the occupation in the first place-and may end up contributing to the high rates of turnover among teachers. As a result, such reforms may not only fail to solve the problems they seek to address by offering a wrong prescription, but they may also end up making things worse. If top-down policies create an imbalance between power and responsibility, that is, if such policies hold teachers accountable for activities they do not control, they may decrease the very thing they seek to fosterimprovements in teacher performance.

\section{The Roots of the Teacher Quality Problem- An Alternative Hypothesis}

In this section I offer an alternate hypothesis, drawn from the sociology of organizations, occupations, and work, to explain the problem of teacher quality and also the popularity of the four conventional explanations described above. From this perspective problems of teacher quality, low entry standards, chronic teacher turnover, teacher misassignment, and highly centralized workplaces are not new issues, and all can be traced to a common root-the stature and standing of the teaching occupation. Unlike in some European and Asian nations, in this country elementary and secondary school teaching has been largely treated as semiskilled work since the development of public school systems in the late 19th century (Etzioni, 1969; Lortie, 1975; Tyack, 1974). In his classic work, The Sociology of Teacbing (1932), Willard Waller, for example, noted that, "The difficulties of the teacher ... are greatly increased by the low social standing of the teaching profession and its general disrepute in the community at large. . . . Concerning the low social standing of teachers much has been written. The teacher in our culture has always been among the persons of little importance and his place has not changed for the better in the last few decades" (pp. 11, 58). Similarly, Mills (1951), in his classic study White Collar, classified schoolteachers as the "proletarians of the professions" (p. 129).

From this alternate perspective, the basis of occupational status lies in control over an important and scarce resource, such as knowledge 
of the causes of, and cures for, life threatening disease, as in the case of the medical profession (Abbott, 1988; Simpson, 1985). The demand for and importance of resources is tied to their scarcity or perceived scarcity. If the resource is something that is widely familiar or available, then the occupation will have difficulty claiming a monopoly of skill and jurisdiction and, thus, will have difficulty gaining the status associated with traditional professions (Wilensky, 1964).

Analysts of work and occupations have long classified teaching as a relatively complex form of work, characterized by uncertainty, intangibility, and ambiguity and requiring a high degree of initiative, thought, judgment, and skill to do well (e.g., Bidwell, 1965; Cohen, Raudenbush, \& Ball, 2003; Lortie, 1975; Shulman, 1986). For example, in a comparative study of a number of occupations, Kohn and Schooler (1983) concluded that secondary teaching involved greater substantive complexity than the work of accountants, salespersons, machinists, managers, and officials in service industries and in the retail trade. What the work of elementary and secondary teachers lacks is not complexity but occupational legitimacy and prestige-leading sociologists to categorize teaching as a semi-profession (Etzioni, 1969; Lortie, 1969; Simpson, 1985). Although the work is relatively complex, the technical base of teaching does not appear to go beyond what the public thinks it knows. In other words, regardless of the reality, the public does not view teaching as equally skilled, sophisticated, intellectually difficult, or advanced work in comparison with the traditional professions.

Part of this public definition and perception may be traced to an unusual aspect of teaching-it is one of the few occupations whose clients have had extensive prior exposure to the work and its practitioners. In short, teaching is an occupation which many nonpractitioners believe they understand. Another factor closely tied to occupational status is gender-three fourths of the teaching force are women. The traditional professions, until recently, have been male dominated. In contrast, predominantly female occupations, such as teaching, have always been of lower prestige and status in the United States (Ingersoll, 2000).

\section{Teacbing as a Semi-Profession}

From this occupational-status perspective, the semiprofessional stature of this feminized work is a large factor behind the first two of the four issues discussed in this chapter-entry requirements and shortages. Teaching is an occupation that has historically relied on recruitment, and not retention, to solve its staffing needs and problems. The 
emphasis was on ease of entry rather than raising admission standards or increasing teacher salaries. After the inception of the public school system in the late 19 th century, teaching was socially defined and treated as a temporary line of work suitable for women, prior to their "real" career of child rearing (e.g., Lortie, 1975; Tyack 1974). For men, teaching was socially defined as a stepping stone to their "real" career in one of the male-dominated skifled blue-collar occupations or whitecollar professions. Indeed, historically there was an ambivalence toward persistors in teaching, especially males, who had to account for why they continued to be "merely" teachers. To this day, low preservice training standards and requirements, relatively unselective entry criteria, and front-loaded salaries that pay newcomers relatively high salaries compared with veterans all tend to favor recruitment over retention. Moreover, low pay, isolated job conditions, little professional autonomy, and little sense of a career ladder all undermine longer-term commitment to teaching as a career and profession. Given these occupational characteristics, cyclic staffing problems, misdiagnosed as shortages, are to be expected.

The semiprofessional status of this feminized work also explains the irony, mentioned earlier, surrounding the relatively high scrutiny of teaching's relatively low entry requirements. Why is there such ongoing interest, compared with other occupations, in documenting and challenging whether teacher qualifications matter? Compared with other occupations, why is there social pressure to continually attempt to prove that teaching is a highly complex kind of work and that it takes both ability and advanced training to do well? In short, why is there a double standard?

From an occupational-status perspective, underlying the skepticism and double standard is the assumption that teaching is less complex and requires less ability and training than many other kinds of occupations and professions. Thus, for example, the assumption is that working with children and youth is less complex and requires less expertise than working with buildings (engineers), teeth (dentists), or financial accounts (accountants) or doing academic research (professors). In plain terms, the underlying assumption is that teaching is not especially difficult work to do well.

The semiprofessional status of teaching also explains the prevalence of out-of-field teaching - the third issue discussed in this chapter. The comparison with traditional professions is stark. Few would require cardiologists to deliver babies, real estate lawyers to defend criminal cases, chemical engineers to design bridges, or sociology professors to 
teach English. This also applies for the high-skill blue-collar occupations-for example, few would ask an electrician to solve a plumbing problem. The commonly held assumption is that such traditional maledominated occupations and professions require a great deal of expertise and, thus, specialization is necessary. In short, for well-paid, wellrespected professions and occupations, it is less acceptable to lower skill standards as a mechanism to increase the labor supply. In contrast, underlying out-of-field teaching appears to be the assumption that female-dominated, precollegiate school teaching requires far less skill, training, and expertise than many other occupations and professions and that specialization is less necessary and, thus, it is appropriate to use teachers like interchangeable blocks. Moreover, the tendency to misdiagnose these human resource management practices as deficits in teacher training or teacher supply further reflects the semiprofessional status of teaching.

Finally, the semiprofessional status of teaching also explains the fourth issue discussed in this chapter-the distribution of control in schools. One of the most important factors associated with the degree of professionalization and the status of an occupation is the degree of power and control practitioners hold over workplace decisions (Freidson, 1973, 1986; Kohn \& Schooler, 1983; Mills, 1951; Perrow, 1986; Simpson, 1985). Professionalized employees usually have control and autonomy approaching that of senior management when it comes to organizational decisions surrounding their work. Academics, for example, often have equal or greater control than that of university administrators over the content of their teaching and research and over the hiring of new colleagues, and through the institution of peer review, over the evaluation and promotion of members and thus, over the ongoing content and character of the profession. Members of lowerstatus occupations usually have little say over their work. The SASS data show that in comparison with traditional professions, teachers have only limited authority over key workplace decisions, such as which courses they are assigned (or misassigned) to teach.

There is no question that some teachers are poorly trained, perform poorly, or are inadequate for the job in one way or another. Moreover, it is neither convincing nor valid to simply pass the blame for low-quality teaching and educational failure elsewhere-for instance, onto families. Teachers are important and do have an effect on students, and it is appropriate to scrutinize their training, qualifications, and performance. However, from an occupational-status perspective, solving the teacher quality problem will require addressing its 
underlying systemic roots. From this perspective, in order to improve the quality of teachers and teaching, it will be necessary to improve the quality of, and respect afforded, the teaching job and occupation. Moreover, piecemeal reform will not accomplish systemic change. Changes to entry standards, training, rewards, autonomy, and accountability must be enacted in concert to succeed. Increases in one must be accompanied by increases in the others. Simply raising preservice entry standards without also raising inservice rewards will not improve the quality of prospective entrants. Raising either entry standards or inservice rewards without also ensuring inservice accountability will not improve quality. Similarly, accountability and autonomy must be linked. Delegating power without commensurate responsibility is irresponsible and can even be dangerous and harmful. In other words, giving teachers more autonomy alone is not the answer. Likewise, accountability without commensurate power is unfair and can also be harmful. It does not make sense to hold somebody accountable for something they do not control, nor does it make sense to give someone control over something for which they are not held accountable. All of these individual changes are necessary, but none alone are sufficient to accomplish the larger systemic goal-ensuring quality teachers in every classroom. 


\section{REFERENCES}

Abbott, A. (1988). The system of professions: An essay on the division of expert labor. Chicago: University of Chicago Press.

Allen, M. (2003). Eight questions on teacber preparation: What does the research say? Denver, CO: Education Commission of the States.

American Council on Education. (1999). To touch the future: Transforming the way teachers are taught. Washington, DC: Author.

Ballou, D. (1996). Do public schools hire the best applicants? Quarterly Foumal of Economics, $111(1), 97-133$.

Bidwell, C. (1965). The school as a formal organization. In J. March (Ed.), Handbook of organizations (pp. 973-1002). Chicago: Rand McNally-

Bluedorn, A.C. (1982). A unified model of turnover from organizations. Human Relations, 35, 135-153.

Boe, E., \& Gilford, D. (1992). Teacher supply, demand and quality. Washington, DC: National Academy Press.

Braverman, H. (1974). Labor and monopoly capitalism. New York: Monthly Review Press.

Burawoy, M. (1979). Manufacturing consent: Changes in the labor process under monopoly capitalism. Chicago: University of Chicago Press.

Callahan, R. (1962). Education and the cult of efficiency. Chicago: University of Chicago Press.

Carnegie Foundation for the Advancement of Teaching. (1990). The condition of teaching. New York: Carnegie Foundation.

Cohen, D., Raudenbush, S., \& Ball, D. (2003). Resources, instruction and research. Educational Evaluation and Policy Analysis, 25(2), 119-142.

Cohen, M., March, J., \& Olsen, J. (1972). A garbage can theory of organizational decision making. Administrative Science Quarterly, 17, 1-25.

Coleman, J., \& Hoffer, T. (1987). Public and private schools: The impact of communities. New York: Basic Books.

Committee for Economic Development. (1996). American workers and economic change. New York: Author.

Conley, S. (1991). Review of research on teacher participation in school decision making. In G. Grant (Ed.), Reviezw of Research in Education, 17, 225-266. Washington, DC: American Educational Research Association.

Darling-Hammond, L. (1984). Beyond the commission reports: The coming crisis in teacbing. Santa Monica, CA: Rand Corporation.

Darling-Hammond, L. (1999). Teacher quality and student acbievement: $A$ review of state policy evidence. Center for the Study of Teaching and Policy, University of Washington.

Delany, B. (1991). Allocation, choice and stratification within high schools: How the sorting machine copes. American 7oumal of Education, 99(2), 181-207.

Durkheim, E. (1925/1961). Moral education: $A$ study in the theory and application of the sociology of education, E.K. Wilson and H. Schnurer (Trans.). New York: Free Press.

Education Week. (2000). Quality counts: A report on education in the 50 states. Washington, $\mathrm{DC}$ : Author.

Elmore, R. (2000). Building a new structure for school leadership. New York: Albert Shanker Institute.

Etzioni, A. (1969). (Ed.). The semiprofessions and their organizations: Teachers, nurses and social workers. New York: Free Press.

Finn, C., Kanstoroom, M., \& Petrilli, M. (1999). The quest for better teachers: Grading the states. Washington, DC: Thomas B. Fordham Foundation.

Freidson, E. (1973). The professions and their prospects. Beverly Hills, CA: Sage.

Freidson, E. (1986). Professional powers: $A$ study in the institutionalization of formal knowledge. Chicago: University of Chicago Press.

Fullan, M. (1991). The new meaning of educational change. New York: Teachers College Press. 
Grant, G. (1988). The world we created at Hamilton High. Cambridge, MA: Harvard University Press.

Greenwald, R., Hedges, L., \& Laine, R. (1996). The effect of school resources on student achievement. Review of Educational Research, 66, 361-396.

Hafner, A., \& Owings, J. (1991). Careers in teaching: Following members of the bigh school class of 1972 in and out of teaching (NCES Report No. 91-470). Washington, DC: U.S. Department of Education, National Center for Education Statistics.

Hall, R. (1968). Professionalization and bureaucratization. American Sociological Review, 33, $92-104$.

Hanushek, E., \& Rivkin, S. (2004, forthcoming). How to improve the supply of high quality teachers. In D. Ravitch (Ed.), Brookings papers on education policy. Washington, DC: Brookings Institution.

Henke, R., Chen, X., \& Geis, S. (2000). Progress through the pipeline: 1992-93 College graduates and elementary/secondary scbool teaching as of 1997. Washington, DC: National Center for Education Statistics.

Hirsch, E., Koppich, J., \& Knapp, M. (2001). Revisiting what states are doing to improve the quality of teacbing: An update on patterns and trends. Center for the Study of Teaching and Policy, University of Washington, Seattle.

Hodson, R., \& Sullivan, T. (1995). Professions and professionals. In R. Hodson \& T.A. Sullivan (Eds.), The social organization of work (pp. 287-314). Belmont, CA: Wadsworth.

Hom, P., \& Griffeth, R. (1995). Employee turnover. Cincinnati: South-Western Publishing. Huling-Austin, L. (1990). Teacher induction programs and internships. In W.R. Houston (Ed.), Handbook of researcb on teacher education (pp. 535-548). Reston, VA: Association of Teacher Educators.

Ingersoll, R. (1999). The problem of underqualified teachers in American secondary schools. Educational Researcher, 28, 26-37.

Ingersoll, R. (2000). The status of teaching as a profession. In J. Ballantine \& J. Spade (Eds.), Scbools and society: $A$ sociological perspective (pp. 115-129). Belmont, CA: Wadsworth Press.

Ingersoll, R. (2001). Teacher turnover and teacher shortages: An organizational analysis. American Educational Research foumal, 38(3), 499-534.

Ingersoll, R. (2003a). Who controls teachers' work? Power and accountability in America's schools. Cambridge, MA: Harvard University Press.

Ingersoll, R. (2003b). Is there really a teacher shortage? Center for the Study of Teaching and Policy, University of Washington, Seattle. Available: http://ctpweb.org

Ingersoll, R. (2004). Why some schools have more underqualified teachers than others. In D. Ravitch (Ed.), Brookings papers on education policy. Washington, DC: Brookings Institution.

Kirst, M. (1989). Who should control the schools? In T.J. Sergiovanni \& J. Moore (Eds.), Scbooling for tomorrow. Boston: Allyn and Bacon.

Kohn, M., \& Schooler, C. (1983). Work and personality. Norwood, New Jersey: Ablex.

Lortie, D. (1969). The balance of control and autonomy in elementary school teaching. In A. Etzioni (Ed.), The semiprofessions and their organizations: Teachers, nurses and social workers (pp. 1-53). New York: Free Press.

Lortie, D. (1975). Scbool teacber. Chicago: University of Chicago Press.

Meyer, J., \& Scott, W.R. (1983). Organizational environments: Ritual and rationality. Beverly Hills, CA: Sage.

Mills, C.W. (1951). White collar. New York: Oxford.

Mobley, W. (1982). Employee tumover: Causes, consequences and control. Reading, MA: Addison-Wesley.

Murnane, R., \& Raizen, S. (1988). Indicators of teaching quality. In R. Murnane \& S. Senta (Eds.), Improving indicators of the quality of science and matbematics education in grades K-12 (pp. 90-118). Washington, DC: National Academy Press. 
Murnane, R., Singer, J., Willett, J., Kemple, J., \& Olsen, R. (Eds.). (1991). Who will teach? Policies that matter. Cambridge, MA: Harvard University Press.

National Academy of Sciences. (1987). Toward understanding teacber supply and demand. Washington, DC: National Academy Press.

National Commission on Excellence in Education. (1983). A nation at risk: The imperative for educational reform. Washington, DC: Government Printing Office.

National Commission on Teaching and America's Future. (1996). What matters most: Teaching for America's future. New York: NCTAF.

National Commission on Teaching and America's Future. (1997). Doing what matters most: Investing in quality teaching. New York: NCTAF.

National Education Association. 1972, 1982, 1987, 1992, 1996. Status of the American public school teacher. Washington, DC: National Education Association.

Parsons, T. (1959).The school class as a social system: Some of its functions in American society. Harvard Educational Review, 29, 297-318.

Pascarella, E., \& Terenzini, P. (1991). How college affects students: Findings and insights from twenty years of research. San Francisco: Jossey-Bass.

Perrow, C. (1986). Complex organizations: A critical essay. New York: Random House.

Price, J. (1977). The study of turnover. Ames, IA: Iowa State University Press.

Price, J. (1989). The impact of turnover on the organization. Work and Occupations, 16, $461-473$.

Raudenbush, S., Fotiu, R., \& Cheong, Y. (1999). Synthesizing results from the trial state assessment. Fournal of Educational and Bebavioral Statistics, 24(4), 413-438.

Robinson, V. (1985). Making do in the classroom: A report on the misassignment of teachers. Washington, DC: Cotnncil for Basic Education and American Federation of Teachers.

Schlecty, P., \& Vance, V. (1981). Do academically able teachers leave education? The North Carolina case. Pbi Delta Kappan, 63, 105-112.

Shulman, L. (1986). Those who understand: Knowledge growth in teaching. Educational Researcher, 15, 4-14.

Simpson, R. (1985). Social control of occupations and work. Annual Review of Sociology, 415-436.

Smylie, M.A., \& Wenzel, S.A. (2003). The Chicago Annenberg Challenge: Successes, failures, and lessons for the future (Final Technical Report of the Chicago Annenberg Research Project). Chicago: Consortium on Chicago School Research, University of Chicago.

Strober, M., \& Tyack, D. (1980). Why do women teach and men manage? Signs, 5, 499500.

Texas Center for Educational Research. (2000). The cost of teacber turnover. Austin, TX: Texas State Board for Educator Certification.

Tyack, D. (1974). The one best system. Cambridge, MA: Harvard University Press.

Tyler, W. (1988). School organization. New York: Croom Helm.

Waller, W. (1932). The sociology of teaching. New York: Wiley.

Wang, A., Coleman, A., Coley, R., \& Phelps, R. (2003). Preparing teachers around the world. Princeton, NJ: Educational Testing Service.

Weaver, T. (1983). America's teacher quality problem: Alternatives for reform. New York: Praeger Publishers.

Weick, K. (1976). Educational organizations as loosely coupled systems. Administrative Science Quarterly, 21, 1-19.

Wilensky, H. (1964). The professionalization of everyone? American fournal of Sociology, $70,137-158$. 